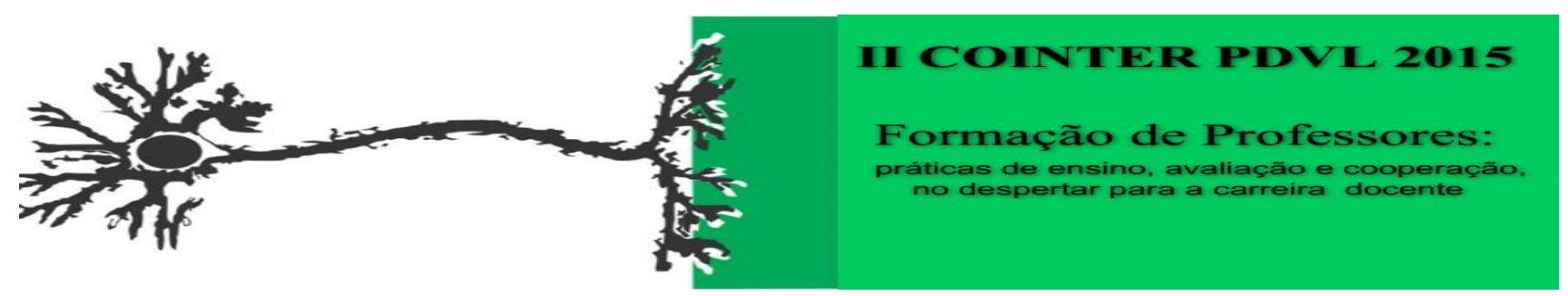

\title{
FLIPPED CLASS E DESAFIOS EDUCACIONAIS EM DIDÁTICA
}

\author{
Apresentação: Relato de Experiência \\ Vitor Luis da Silva ${ }^{1}$; Alzira de Lucena C. L. Neta ${ }^{2}$; Paulo André da Silva ${ }^{3}$
}

\section{Introdução}

Ser professor, dentre muitas coisas, implica em tomada de decisões em termos metodológicos, em termos de opção de centrar-se no ensino ou centrar-se na aprendizagem. A priorização da aprendizagem não anula o ensino, mas este pode, em algumas situações mais rígidas, anular aquele. A postura de transmissor de informação, do ponto de vista comunicacional, é baseada no conceito de emissor-receptor (MITRE, 2007; VALENTE, 2014).

Entretanto, tal postura não está mais sendo vista como a maneira mais adequada de transmitir o conhecimento, visto que o aluno possui acesso a outras formas de chegar até ele. Propostas novas, dentro da ótica das metodologias ativas, como o Flipped Class - Sala de Aula Invertida (VALENTE, 2014), como método de ensino, em especial na formação do professor de educação básica é uma maneira motivadora e dinâmica de desenvolver o conhecimento no licenciando.

\section{Relato de Experiência}

O Flipeed Class foi aplicado com a turma do segundo período de Licenciatura em Ciências Biológicas do Centro Acadêmico de Vitória (UFPE/CAV) para a disciplina de Didática, sob a orientação do Prof. Paulo André e da Profa. Priscilla Pontes. Foi proposta à turma uma forma ativa de desenvolver os conteúdos próprios da disciplina e combinado um modelo avaliativo de acordo com o que era apresentado: as fontes de pesquisas, as apresentações das resoluções hipotéticas, sincronia entre os integrantes do grupo e cumprimento de cronograma previamente planejado.

O trabalho teve como título: "Desafios Educacionais", o qual consistiu em situações problema com seis temáticas distintas que foram distribuídas entre os seis grupos formados em sala de aula. Para acompanhamento do processo sugeriu-se o uso da ferramenta de interação "Evernote";

\footnotetext{
${ }^{1}$ Lic. Ciências Biológicas, Universidade Federal de PE, vitorluismqs@gmail.com

${ }^{2}$ Lic. Ciências Biológicas, Universidade Federal de PE, lucenna.isaa1810@hotmail.com

${ }^{3}$ Mestre em Educação, Universidade Federal de Pernambuco, profe.pas@gmail.com
} 
um aplicativo on-line, com licença gratuita para uso na web e multiplataforma, possibilita o trabalho compartilhado. Com esse aplicativo, cada grupo teve a possibilidade de armazenar todas as informações pertinentes ao trabalho, construindo notas em cadernos que puderam ser compartilhados entre os envolvidos.

Os desafios foram lançados em uma rede social que todos já faziam parte e explicados presencialmente em sala. Foi determinado um cronograma dividido em quatro momentos de apresentações entre as equipes. (i) Encaminhamento, no qual consistiu de apresentação dos desafios e possíveis encaminhamentos para resolução dos problemas. (ii) Debate, momento para os alunos trazerem informações de suas pesquisas para amadurecimento das ideias. Nesse momento o docente analisou o conteúdo, fez questionamentos, tirou dúvidas e norteou os grupos àquilo que julgou ser necessário. (iii) Síntese, momento que os alunos, de posse de uma quantidade maior de informações, apresentaram esclarecimentos e possíveis soluções aos problemas e relataram novas dificuldades encontradas no processo. (iv) Mostras de soluções; cada grupo com seus argumentos e levantamentos bem alicerçados, expôs as possíveis soluções ao problema, adotando uma delas como minimamente convincente, justa, dentro dos parâmetros propostos.

\section{Considerações}

O Flipped Class, acima descrito, nos colocou como protagonistas na relação ensinoaprendizagem, estimulando a aprendizagem significativa e fomentando um desenvolvimento mais abrangente. Essa experiência didática nos lança a visões de ações diferenciadas no fazer pedagógico como alternativa ao modelo tradicional de transmissão/reprodução de conhecimentos.

\section{Referências}

VALENTE, J. A. Blended learning e as mudanças no ensino superior: a proposta da sala invertida. Educar em Revista, Curitiba, Brasil, 2014. Edição Especial n. 4/2014, p. 79-97. Editora UFPR.

MITRE, Sandra Minardi et al. Metodologias ativas de ensino-aprendizagem na formação profissional em saúde: debates atuais. Ciênc. saúde coletiva, Rio de Janeiro, v.13, supl.2, p.21332144, Dec. 2008. Disponível em < http://goo.gl/3i2hb6>. Aceso em 07 Nov. 2015. 